\title{
THE EFFECT OF USING WASTE PLASTIC AND WASTE GLASS ON THE ASPHALT PAVEMENT PROPERTIES
}

\author{
Vivek Singh ${ }^{1}$, Rakesh Sakale ${ }^{2}$ \\ ${ }^{1}$ M. Tech, Peoples University, Bhopal \\ ${ }^{2} \mathrm{HOD} \&$ Associate Professor
}

\begin{abstract}
In this paper, the effect of using waste plastic and waste glass as a modifier in bituminous mix is investigated. HDPE waste plastic is used as modifier in bitumen of VG30 grade and waste glass bottle cullet as fine material in bituminous mix. The initial study was performed on virgin bitumen to investigate the physical characteristic of virgin unmodified binder then HDPE plastics are mixed in virgin bitumen to modify the physical characteristic of bitumen. To mix the HDPE plastic in bitumen $170^{\circ} \mathrm{C}$ blending temperature and 25mins blending time was adopted for manual mixing. Furthermore, Marshall Stability Test has been carried out on Conventional, HDPE modified mix, Glasphalt mix and HDPE Glasphalt bituminous mixtures. Optimum binder content was determined by using five different bitumen contents of 5\%, 5.2\%, 5.4\%, 5.6\% and 5.8\%, and optimum plastic content is by using five plastic contents of $0.2 \%, 0.4 \%, 0.6 \%, 0.8 \%$ and $1 \%$, and optimum glass content is by four different glass content of $2.5 \%, 5 \%$, $7.5 \%$ and $10 \%$. Form the investigation of Marshall Stability test, $5.66 \%$ OBC, $0.6 \%$ OPC and 7.5\% OGC is determined. HDPE modified Glasphalt mixture was prepared at optimum binder and Optimum plastic content with four different glass content. It is concluded that, with mixing of HDPE into both binder and mixtures properties are completely modified and shows good resistive nature temperature variation and seepage of water. HDPE modified Glasphalt mixture shows increased compressive strength than unmodified Glasphalt mixture. It is also concluded that waste plastic and waste glass can be used in bituminous mixture as a binder solution and fine material respectively. It is feasible to use and recycle waste plastic and glass in bituminous mixture as to protect environment and on economic point of view.
\end{abstract}

Keywords: Bituminous mix, HDPE, Glasphalt, Marshall Stability test, Plastic Waste, Glass Waste.

\section{INTRODUCTION}

India has a road network of over 5,472,144 kilometers $(3,400,233$ mile) as on 31 March 2015 , the second largest road network in the world. At $1.66 \mathrm{~km}$ of roads per square kilometer of land, the quantitative density of India's road network is higher than that of Japan (0.91) and the United States (0.67), and far higher than that of China (0.46), Brazil (0.18) or Russia (0.08), ( Ministry of Road Transport \& Highways). The condition of bituminous road is getting worse day by day due to heavy axle load, temperature variation and heavy rains. To improve the performance of flexible pavements an innovative modifying agent should have to mix with it. Fine material has two important roles in mix, first is to fill the voids of coarse aggregate and second is to provide more contact between aggregates. Bitumen is used as a binding agent between aggregates and filler material in bituminous mix but its greater disadvantage is its temperature susceptibility. Bitumen is brittle at lower temperature and ductile at higher temperature. At high temperature, it turns in liquid state. But its property can be modify by adding such a polymer which is friendly with its nature, have same quality as bitumen and economical. Use of waste plastic to improve the quality of virgin bitumen is good initiative as waste management and economic benefits.
Waste glasses are grouped as industrial solid wastes. Most of the industrial solid wastes can be used in highway constructions and road layers from top layer to subgrade. Higher performance and environmentally friendly road pavements can be constructed by the use of by-products instead of traditional materials ( Mehmet Saltan, 2015). The property of bituminous mixtures can also be improved by introducing some new materials into the mixtures and one of them is waste glass. Waste glass can be used as fine material and mineral filler in bituminous mix. Waste glasses are crushed at required gradation and size then mixed with bituminous mixtures for surface or wearing course. Many countries and researches have already showed its magical effect in pavement construction.

The aim of this research is to investigate the effect of waste plastic and waste glass incorporated with each other on the properties of bituminous mix. In past, lots of studies has been performed on this field with using waste plastics and waste glass as modifier in bituminous mixes but HDPE waste plastic and waste glass have never incorporated with other in mix. 


\section{EXPERIMENTAL PROGRAMME}

\subsection{Material Used}

\subsubsection{Bitumen}

Bitumen of VG30 or $60 / 70$ grade were used in this study. Table 1 shows the physical requirements of VG30 bitumen as per IS73-2013.

\subsubsection{Waste Plastic}

HDPE Plastic waste was used as modifier in this study. The plastic bags were collected and washed then shredded into fibers of size 50x6mm. Figure 1 shows the shredded HDPE plastics.

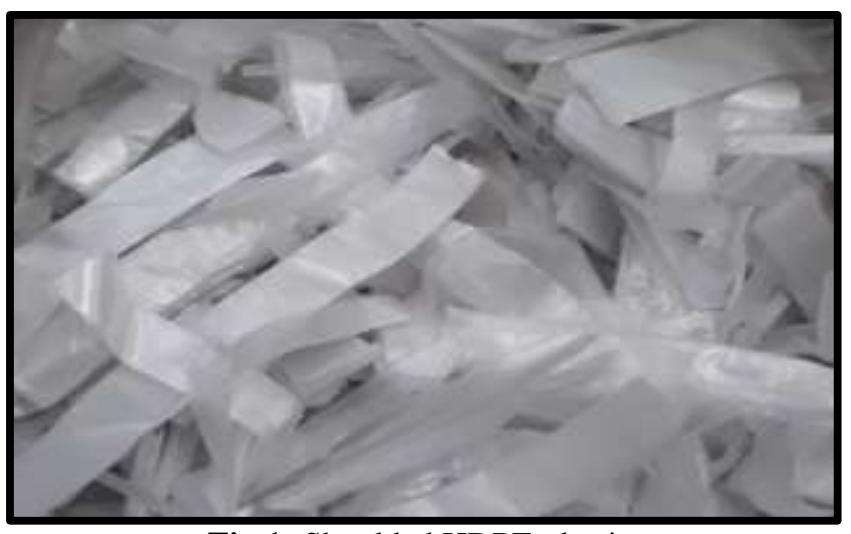

Fig 1: Shredded HDPE plastic

\subsubsection{Aggregates}

Aggregates were tested to analyze its physical properties and test results are shown on Table 2 .

\subsubsection{Waste Glass}

Waste glasses are collected and washed then crushed for required gradation. Gradation of crushed glass is shown on figure 2.

\subsection{Preparation of HDPE Modified Binder}

Bitumen is heated about $170^{\circ} \mathrm{C}$ and HDPE plastics were mixed in melted condition. The mixing is done manually, so $170^{\circ} \mathrm{C}$ blending temperature and 20 mins blending time is adopted for blending of modified bitumen.

\subsection{Preparation of Glass and HDPE Modified}

\section{Mixtures}

Graded aggregate and crushed glass was taken separately for the preparation of conventional and glass modified mixtures. First sample were prepared for conventional mix, second for HDPE modified mix, third for Glass modified mix and final mix is prepared for both glass and HDPE.

Table 1: Physical requirements for Bitumen

\begin{tabular}{|l|l|l|l|}
\hline Sl. No. & Description of Test & $\begin{array}{l}\text { Grade of bitumen and its Acceptable } \\
\text { Value }\end{array}$ & $\begin{array}{l}\text { IS } \\
\text { method }\end{array}$ \\
\cline { 3 - 3 } & & VG30 or $(60 / 70)$ & \\
\hline 1 & Penetration at $25^{\circ} \mathrm{C}, 100 \mathrm{~g}, 5 \mathrm{~s}, 0.1 \mathrm{~mm}$ min & 45 & IS: 1203 \\
\hline 2 & Softening point $(\mathrm{R} \& \mathrm{~B}),{ }^{\circ} \mathrm{C}, \mathrm{min}$ & 47 & IS: 1205 \\
\hline 3 & Ductility at $25^{\circ} \mathrm{C}, \mathrm{cm}, \mathrm{min}$ & 40 & IS: 1208 \\
\hline 4 & Specific gravity & 1.000 & IS: 1202 \\
\hline
\end{tabular}

Table 2: Test results of Aggregates

\begin{tabular}{|c|c|c|c|c|c|c|}
\hline $\begin{array}{l}\text { SL. } \\
\text { No. }\end{array}$ & \multicolumn{2}{|c|}{ Description of test } & Property & Test method & Particle size & $\begin{array}{l}\text { Test result } \\
\text { observed }\end{array}$ \\
\hline \multirow[t]{2}{*}{1} & \multirow{2}{*}{\multicolumn{2}{|c|}{ Combined Flakiness and Elongation index }} & \multirow[t]{2}{*}{ Particle Size } & \multirow{2}{*}{ IS:2386 Part 1} & $20 \mathrm{~mm}$ & 23.2 \\
\hline & & & & & $10 \mathrm{~mm}$ & 27.8 \\
\hline \multirow[t]{2}{*}{2} & \multirow{2}{*}{\multicolumn{2}{|c|}{ Aggregate Impact Value }} & \multirow[t]{2}{*}{ Strength } & \multirow[t]{2}{*}{ IS:2386 Part 4} & $20 \mathrm{~mm}$ & 9.8 \\
\hline & & & & & $10 \mathrm{~mm}$ & 10.3 \\
\hline \multirow[t]{2}{*}{3} & \multirow{2}{*}{\multicolumn{2}{|c|}{ Water Absorption }} & \multirow{2}{*}{$\begin{array}{l}\text { Water } \\
\text { Absorption }\end{array}$} & \multirow[t]{2}{*}{ IS:2386 Part 3} & $20 \mathrm{~mm}$ & $0.59 \%$ \\
\hline & & & & & $10 \mathrm{~mm}$ & $0.79 \%$ \\
\hline 4 & \multicolumn{2}{|c|}{ Coating \& Stripping of Bitumen Aggregate } & Stripping & \multicolumn{2}{|l|}{ IS: 6241} & $97.50 \%$ \\
\hline \multirow[t]{2}{*}{5} & \multirow[t]{2}{*}{ Soundness } & Sodium Sulphate & \multirow[t]{2}{*}{ Durability } & \multirow[t]{2}{*}{ IS: 2386 Part 5} & & 1.42 \\
\hline & & Magnesium Sulphate & & & & 1.65 \\
\hline
\end{tabular}




\subsection{Test Conducted}

\subsubsection{Test for Virgin and Modified Bitumen}

As per IS73-2013, physical properties were investigated for virgin and modified bitumen. Table 3 shows the tests results of virgin and modified bitumen.

\subsubsection{Marshall Stability Test}

Marshall test was performed on specimens prepared with conventional mix, HDPE binder, glass mix and HDPE modified glass mix with optimum binder and optimum plastic content for the determination of stability, flow, optimum binder, optimum plastic and optimum dose of glass content.

\section{ANALYSIS OF TEST RESULTS AND}

\section{DISCUSSION}

\subsection{Test Results of Virgin and Modified Binder}

Different percentages of HDPE modifier added to VG30 bitumen affects the physical properties of the binder in terms of Penetration, Ductility, Softening and specific gravity.

\subsubsection{Penetration Test Result}

Penetration value of modified binder decreases significantly with increase in percentage of HDPE modifier. This decrease in penetration shows the hardness of binder. By addition of HDPE plastic waste up to a certain percentages binder become hard. The optimum dose of modifier in VG30 is $0.6 \%$ because further increase in modifier values cannot be acceptable.

\subsubsection{Softening Test Result}

Softening point increased with increase in percentages of modifier. This is good for the location where the seasonal temperature increases so much. The result also showed that lower percentage of modifier is best suitable for pavement construction and higher percentage of modifier may be useful for roofing material.

\subsubsection{Ductility Test Result}

Ductility of binder decreases with increase in percentage of modifier. It means that with addition of HDPE modifier binder is getting brittle, up to $0.4 \%$ the values are in the range. Ductility value less than $40 \mathrm{~cm}$ is not Useful for road work but can be used as crack and joint filler.

\subsubsection{Specific Gravity Test}

Specific gravity of modified binder increases with increase in percentage of HDPE modifier.

\subsection{Test Results of HDPE Modified Mix}

Form the conventional bituminous mix $5.66 \%$ optimum binder content calculated. Taking this optimum binder content HDPE modified mix has been prepared and tested. Table 4 shows the marshal test results of HDPE modified mix.

Marshall Stability is a measure of strength of bituminous mix. Higher the stability of mix greater will be the strength of surface course. Form the results it was observed that with increase in HDPE modifier in bituminous mix stability increases at certain percentage of modifier after then stability decreases with high flow value. In this mix at $0.6 \%$ of modifier, maximum stability observed. Lower Flow value observed in comparison to conventional mix at optimum binder content. This indicates the highly rut resistant mixture for surface course.

Table 3: Test results of virgin and modified bitumen

\begin{tabular}{|l|l|l|l|l|l|}
\hline Bitumen & HDPE \% & Penetration $(\mathbf{m m})$ & Softening $\left(^{\mathbf{0}} \mathbf{C}\right)$ & Ductility $(\mathbf{c m})$ & Specific gravity \\
\hline \multirow{5}{*}{ VG 30 } & 0 & 57.2 & 55 & 61.1 & 1.000 \\
\cline { 2 - 6 } & 0.2 & 52.9 & 61 & 54.4 & 1.002 \\
\cline { 2 - 6 } & 0.4 & 48.9 & 64 & 43 & 1.003 \\
\cline { 2 - 6 } & 0.6 & 41.3 & 70 & 36.4 & 1.005 \\
\cline { 2 - 6 } & 0.8 & 31.5 & 80 & 25.3 & 1.005 \\
\cline { 2 - 6 } & 1.0 & 22.9 & 16.4 & 1.007 \\
\hline
\end{tabular}

Table 4: Marshall test results of HDPE modified mix

\begin{tabular}{|l|l|l|l|l|l|l|l|}
\hline OBC \% & HDPE \% & Stability (KN) & Flow (mm) & Unit wt. $(\mathbf{g m} / \mathbf{c c})$ & Air void (\%) & VMA (\%) & VFB (\%) \\
\hline \multirow{5}{5}{5.66} & $\mathbf{0}$ & 1218 & 3.94 & 2.382 & 2.40 & 18.76 & 87.20 \\
\cline { 2 - 8 } & $\mathbf{0 . 2}$ & 1382 & 2.50 & 2.348 & 3.92 & 20.05 & 80.46 \\
\cline { 2 - 8 } & $\mathbf{0 . 4}$ & 1595 & 3.13 & 2.369 & 3.09 & 19.36 & 84.06 \\
\cline { 2 - 9 } & $\mathbf{0 . 6}$ & 1669 & 3.47 & 2.390 & 2.22 & 18.64 & 88.08 \\
\cline { 2 - 9 } & $\mathbf{0 . 8}$ & 1220 & 3.87 & 2.351 & 3.82 & 19.97 & 80.86 \\
\hline
\end{tabular}




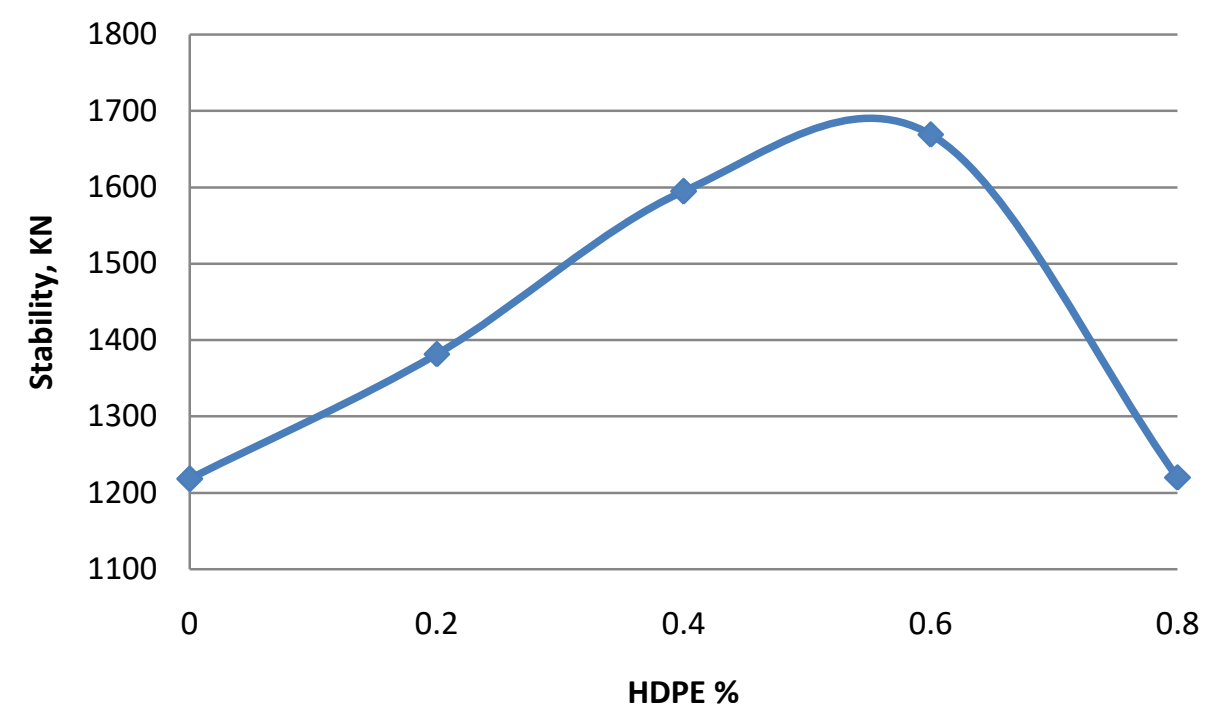

Fig 2: Variation in Stability with HDPE content

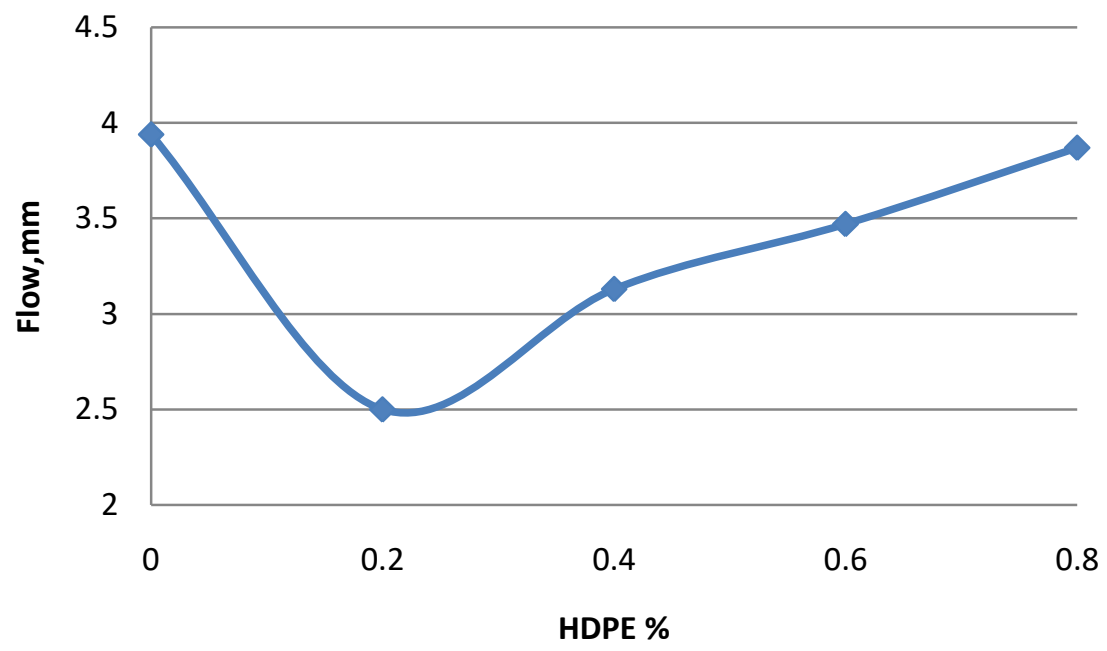

Fig 3: Variation in Flow value with HDPE content

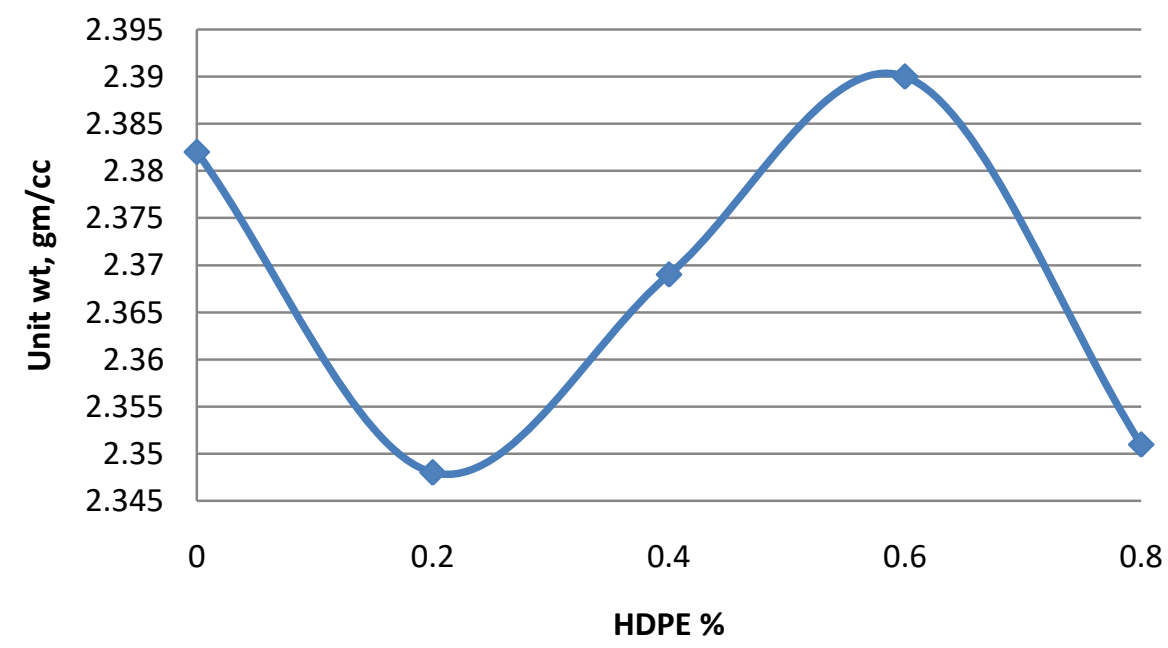

Fig 4: Variation in Unit wt. with HDPE content 


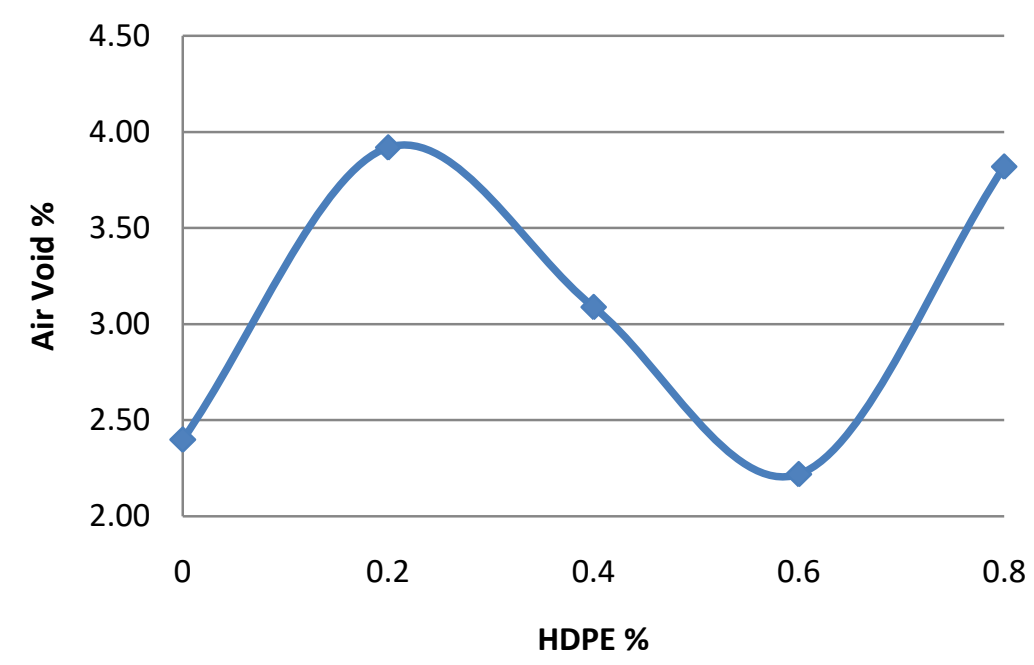

Fig 5: Variation in Air void with HDPE content

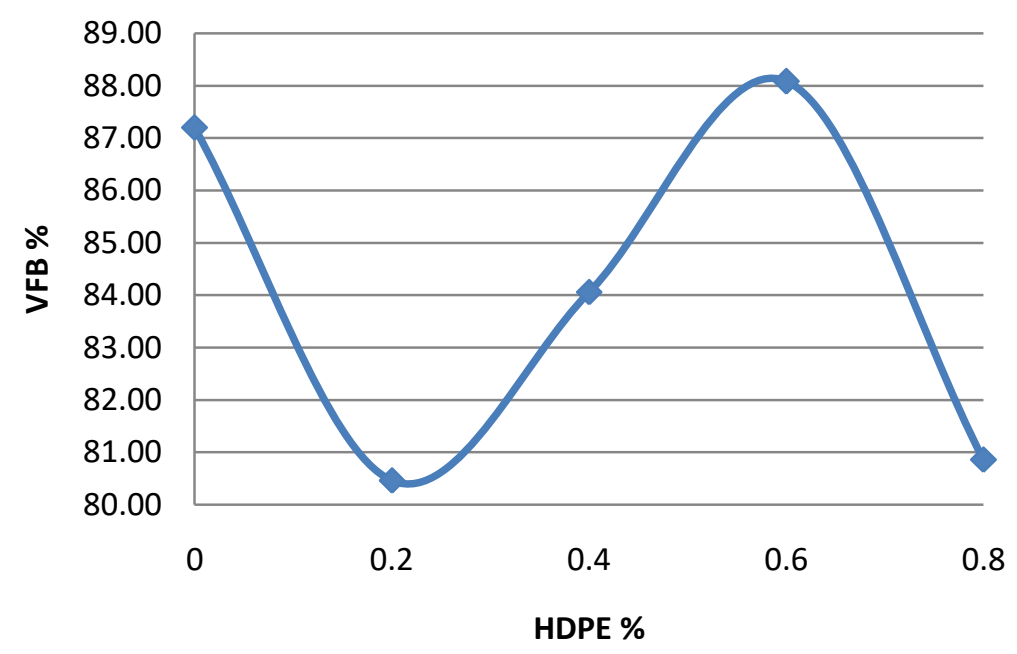

Fig 6: Variation in VFB with HDPE content

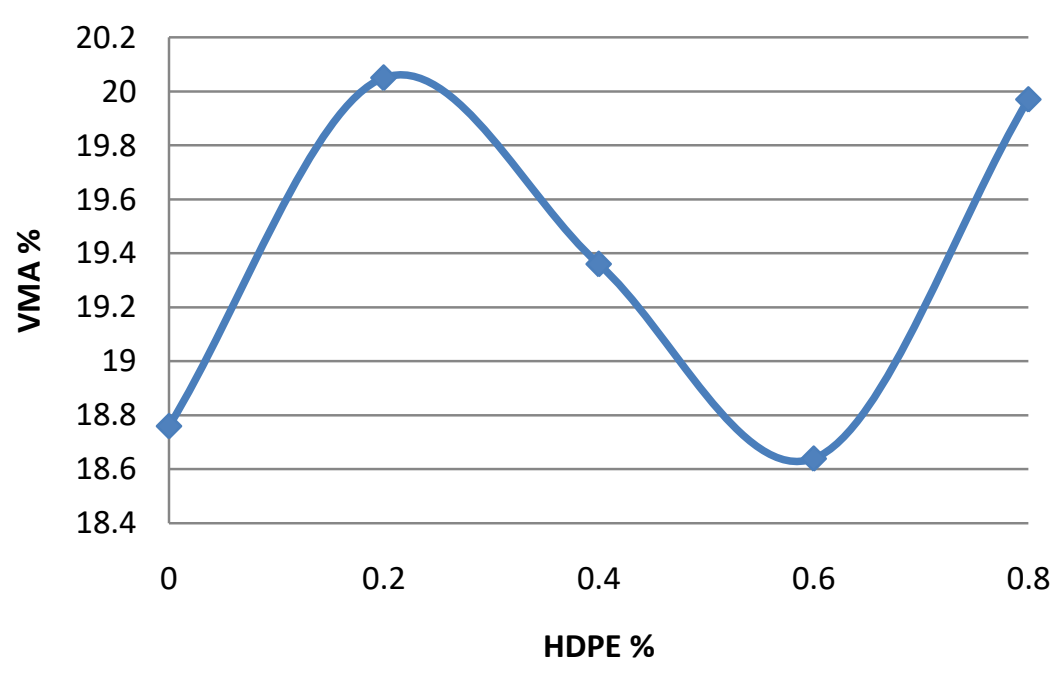

Fig 7: Variation in VMA with HDPE content 


\subsection{Test Results of Glasphalt and HDPE Modified}

\section{Glasphalt Mixture}

Separate mixture was prepared for both classified mixes at optimum binder content and optimum plastic content. From the Marshall stability test results it was observed that original glasphalt mix have lower stability and higher flow value in comparison to HDPE modified glasphalt mixture. Stability increases with mixing of HDPE modified binder into the glasphalt mixtures. From the comparisons between both the mixtures it is concluded that optimum dose of glass cullet in bituminous mix is $7.5 \%$ with optimum doses of bitumen and HDPE modifier. Stability of HDPE modified glasphalt is relatively higher than conventional bituminous mix. It is also concluded that instead of using original glasphalt mixture, HDPE modified glasphalt will good for surface course. Table 5 shows the marshall stability test results of glasphalt mix and table 6 shows the marshall stability test results of HDPE modified glasphalt mixtures. A comparative graphical variation between both the mixtures is also shown below:

Table 5: Marshall test results of glasphalt mixtures

\begin{tabular}{|c|c|c|c|c|c|c|c|}
\hline OBC \% & Glass cullet \% & Stability (Kg) & $\begin{array}{ll}\text { Flow } & \text { value } \\
(\mathbf{m m}) & \end{array}$ & $\begin{array}{l}\text { Unit } \\
(\mathrm{gm} / \mathrm{cc})\end{array}$ & $\begin{array}{l}\text { Air } \\
(\%)\end{array}$ & VMA (\%) & VFB (\%) \\
\hline \multirow[t]{5}{*}{$5.66 \%$} & $0 \%$ & 1218 & 3.94 & 2.382 & 2.4 & 18.76 & 87.20 \\
\hline & 2.5 & 1221 & 3.67 & 2.307 & 5.61 & 21.46 & 77.02 \\
\hline & 5.0 & 1241 & 3.80 & 2.35 & 3.86 & 20.00 & 64.20 \\
\hline & 7.5 & 1267 & 3.88 & 2.372 & 2.93 & 19.23 & 74.77 \\
\hline & 10.0 & 884 & 5.71 & 2.359 & 3.48 & 19.69 & 82.31 \\
\hline
\end{tabular}

Table 6: Marshall test results of HDPE modified glasphalt mixtures

\begin{tabular}{|c|c|c|c|c|c|c|c|c|}
\hline ОВС \% & ОРС \% & $\begin{array}{l}\text { Glass cullet } \\
\%\end{array}$ & $\begin{array}{l}\text { Stability } \\
(\mathrm{Kg})\end{array}$ & $\begin{array}{l}\text { Flow } \\
\text { value } \\
(\mathbf{m m})\end{array}$ & $\begin{array}{l}\text { Unit wt. } \\
(\mathrm{gm} / \mathrm{cc})\end{array}$ & $\begin{array}{l}\text { Air } \\
(\%)\end{array}$ & VMA (\%) & VFB (\%) \\
\hline \multirow[t]{5}{*}{$5.66 \%$} & \multirow[t]{5}{*}{$0.6 \%$} & $0 \%$ & 1669 & 3.47 & 2.390 & 2.22 & 18.64 & 88.08 \\
\hline & & 2.5 & 1689 & 3.46 & 2.342 & 4.19 & 20.38 & 79.35 \\
\hline & & 5.0 & 1724 & 3.85 & 2.355 & 3.63 & 19.81 & 81.70 \\
\hline & & 7.5 & 1766 & 3.93 & 2.362 & 3.37 & 19.60 & 82.79 \\
\hline & & 10.0 & 905 & 4.69 & 2.356 & 3.60 & 19.79 & 81.79 \\
\hline
\end{tabular}

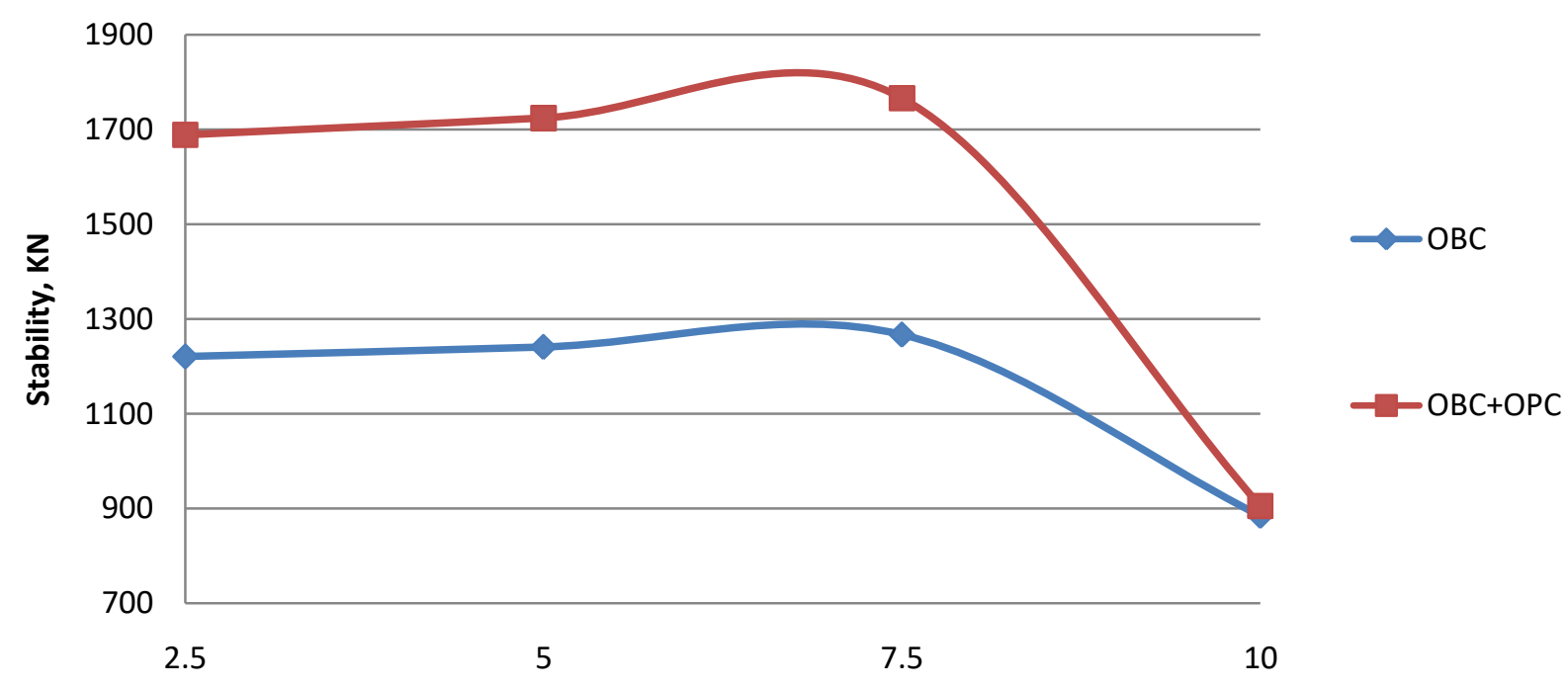

Glass \%

Fig 8: Comparison of Stability between glasphalt and HDPE glasphalt 


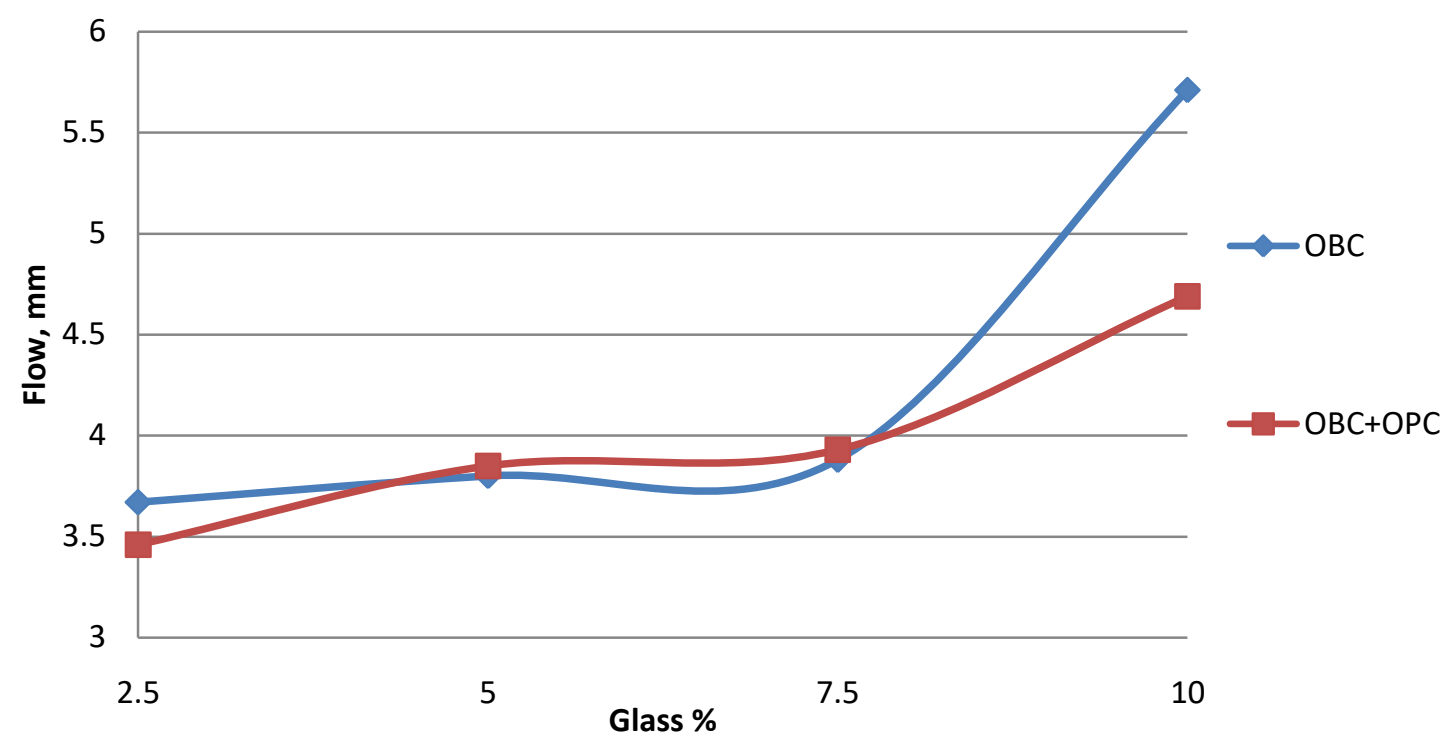

Fig 9: Comparison of flow value between glasphalt and HDPE glasphalt

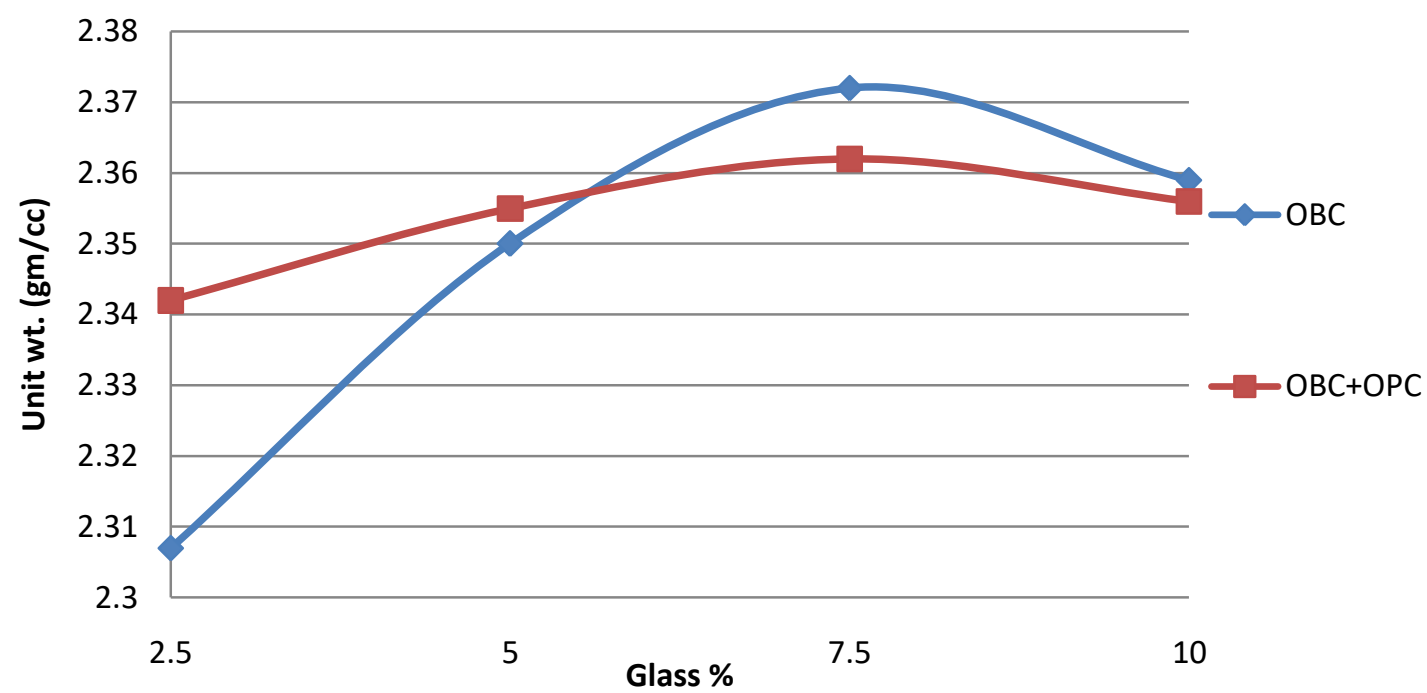

Fig 10: Comparison of Unit wt. between glasphalt and HDPE glasphalt

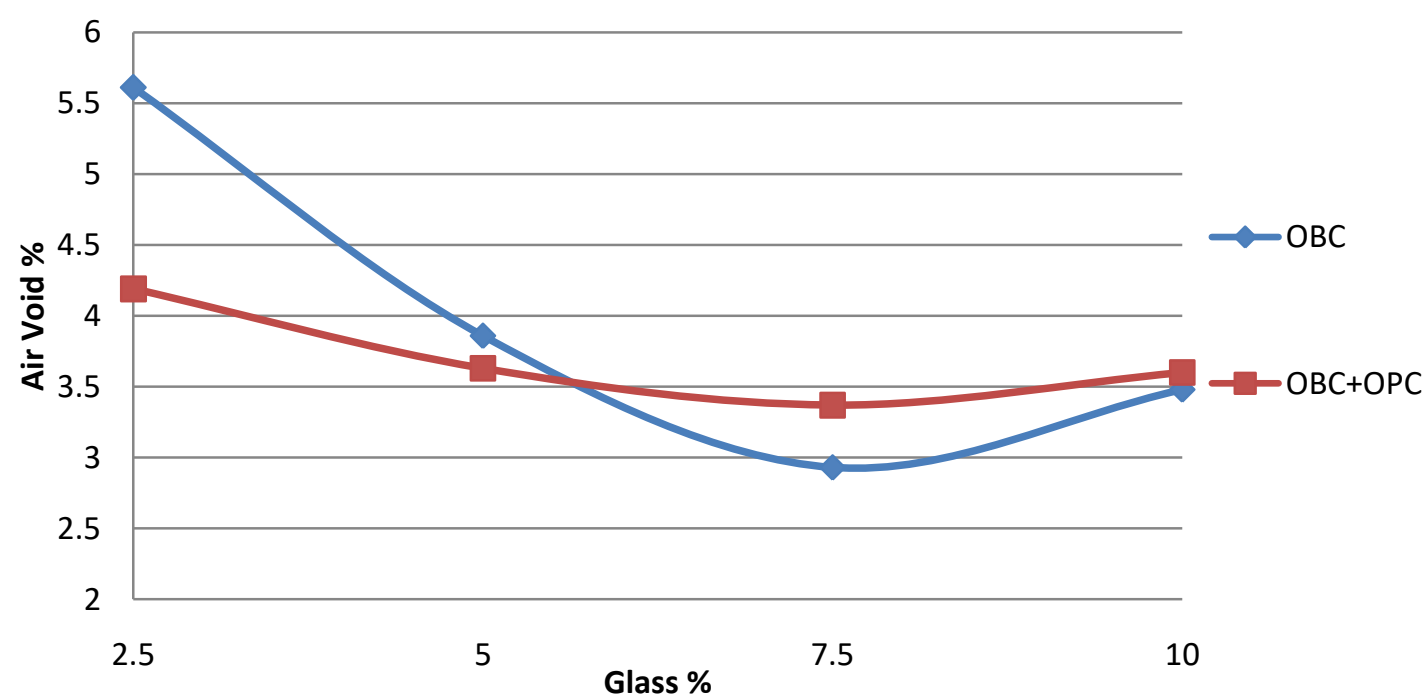

Fig 11: Comparison of Air void between glasphalt and HDPE glasphalt 


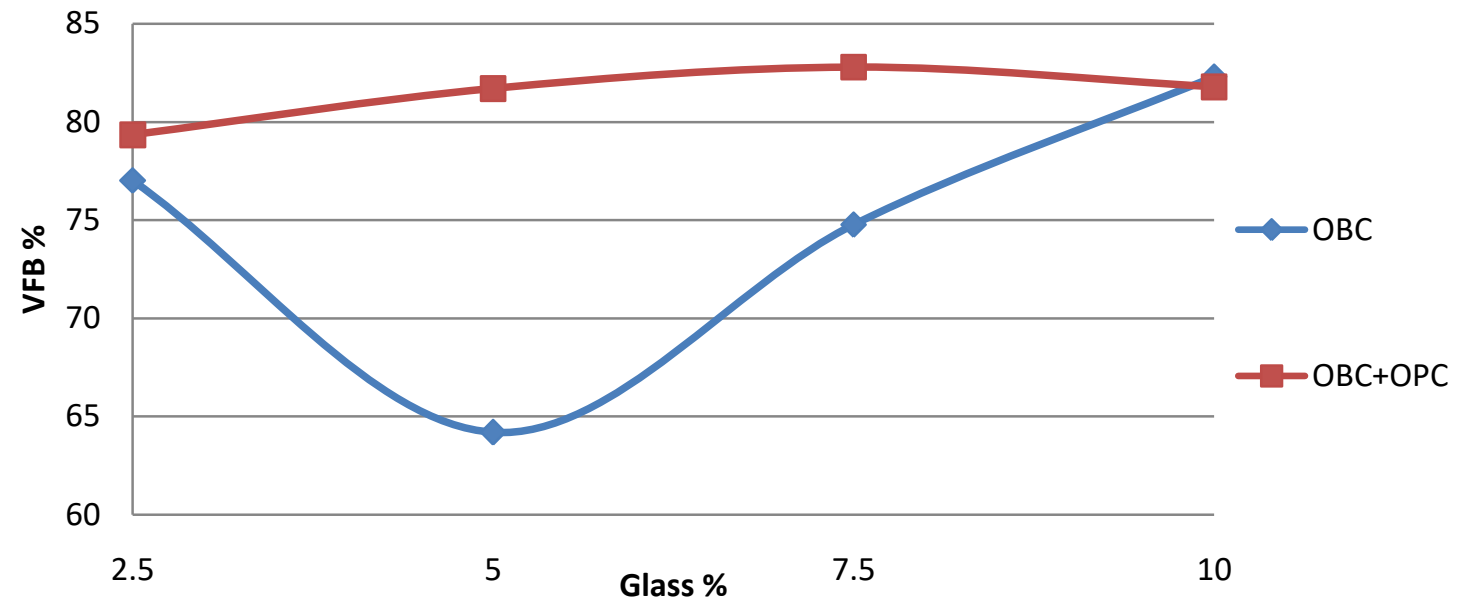

Fig 12: Comparison of VFB between glasphalt and HDPE glasphalt

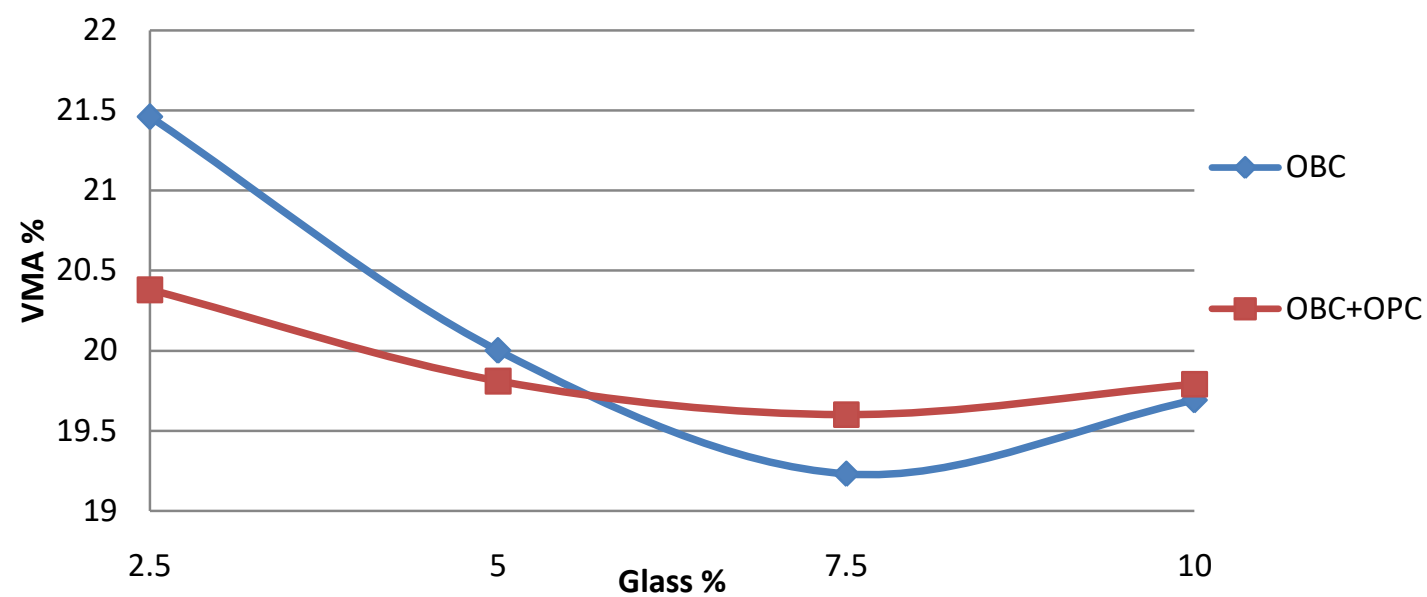

Fig 13: Comparison of VMA between glasphalt and HDPE glasphalt

\section{CONCLUSION}

There are some conclusions which are made from the analysis of test results:

- By mixing of HDPE into the VG30 bitumen, penetration value decreases up to $60 \%$ of $1 \%$ dose of HDPE, but up to $0.4 \%$ of HDPE the value can be accepted. Ductility also decreases with increase in HDPE by $73 \%$ of $1 \%$ HDPE content.

- Softening point increases by mixing of HDPE into bitumen which is good and suitable for high temperature region.

- Decrease in value of Penetration and Ductility shows the hardness and brittleness respectively; of the binder with HDPE mix, which shows the impermeable quality by the modified binder.

- Optimum dose of HDPE in VG30 bitumen is between 0.2 to $0.4 \%$.

- Using Marshall Method of mix design the optimum binder content and optimum plastic has been determined which is $5.66 \%$ and $0.6 \%$ respectively.

- It has been observed that addition of HDPE waste plastic into the conventional mix can enhance the stability of mixture with lesser flow value in comparison with conventional mix, up to a certain dose of HDPE.

- The existence of waste plastic and waste glass cullet in bituminous binder course mixture is considered as an eco friendly material and sustainable management of these waste products in Pavement construction.

- Using glass waste into bituminous pavement mixture is a good initiate to save environment and nature and it is a sustainable management of this waste.

- Glass can be use in place of finer material in bituminous binder course.

- By incorporation of waste plastic and waste glass into the bituminous binder course the stability increase approx. 50\% than conventional mix.

- Optimum dose of waste glass cullet is in the range of 2.5 to $7.5 \%$.

\section{Recommendations}

- In this study only liquor glass bottles were used so further more studies are needed using different types of glass products. 
- In this study only HDPE is incorporated with waste glass, other types of plastics are also need to incorporate with this or other types of waste glass.

- Some other strength characteristic studies are needed to perform on these materials.

- In the present stud plastic is added to mix via wet mixing process. Plastic incorporated with glass cullet can also be used for mixture modification by dry mixing process and should compare the results.

- In this study only VG30 grade bitumen was used, future more studies are needed with these materials using other VG grade bitumen.

- Some of the properties like tensile strength ratio, fatigue behavior, rutting resistance, dynamic and static tensile strength and creep behavior are need to investigate.

\section{REFERENCES}

[1] A. Ahmed (2007), "Improvement of Marshall Properties of the asphalt concrete mixtures using the polyethylene as additive." Eng Technol 2007; 25 (3):383-94.

[2] Arunesh Kumar, Abhishek Kumar Tiwari (2016), “ Utilization of Glass Powder in Cement Concrete Paver Blocks" IJSRD - International Journal for Scientific Research \& Development, Vol. 3, Issue 11, 2016.

[3] ASTM D6927- 2015, "Standard Test Method for Marshall Stability and Flow of Asphalt Mixtures."

[4] Bose, G. Kumar and G. Sharma (2005), "Performance Characteristics of Bituminous Mixes Modified by Waste Plastic Bags" Highway Research Bulletin, 71, Indian Roads Congress, New Delhi: 110.

[5] Bureau of Indian Standards (2004), "Polymer and rubber modified bitumen - Specification" IS: 15462, New Delhi, India.

[6] G.H. Shafabakhsh, Y. Sajed (2014), "Investigation of dynamic behavior of hot mix asphalt containing waste materials; case study: Glass cullet" Construction Materials 1 (2014) 96-103.

[7] Isaac Finkle, Khaled Ksaibati and Timothy Robinson (2007), "Recycled glass utilization in highway construction" Transportation Research Board 86th Annual Meeting January 21-25, 2007, Washington D.C.

[8] IS: 2386 (1963), "Method of test for aggregates for concrete (P - I): Particle size and shape", Bureau of Indian Standards, New Delhi.

[9] IS: 2386 (1963), "Methods of test for aggregates for concrete (P-III): Specific Gravity, Density, Voids, Absorption, Bulking”, Bureau of Indian Standards, New Delhi.

[10] IS: 2386 (1963), "Methods of test for aggregates for concrete (P-IV): Mechanical Properties", Bureau of Indian Standards, New Delhi.

[11] IS: 2386 (1963), "Methods of test for aggregates for concrete (P-V): Soundness", Bureau of Indian Standards, New Delhi.
[12] Ivica Androjic, Sanja Dimter (2016), "Properties of hot mix asphalt with substituted waste glass" Materials and Structures, January 2016, Volume 49, Issue 1-2, pp 249-259.

[13] J.H. Collins, M.G. Bouldin, R. Gelles and A. Berker (1991), "Improved performance of paving asphalts by polymer modification" Proc., Association of Asphalt Paving Technologists, Vol. 60, Association of Asphalt Paving Technologists, Seattle, WA, 43-79.

[14] Joseph Wartman, Dennis G. Grubb and A. S. M. Nasim (2004), "Select Engineering Characteristics of Crushed Glass" Journal of Materials in Civil Engineering Vol. 16, Issue 6 (December 2004).

[15] M. Arabani (2011), "Effect of glass cullet on the improvement of the dynamic behavior of asphalt concrete" Construction and Building Materials 25 (2011) 1181-1185.

[16] M. Ghasemi and S. M. Marandi (2013) "Laboratory studies of the effect of recycled glass powder additive on the properties of polymer modified asphalt binders" IJE transactions a: Basics Vol. 26, No. 10, (October 2013) 1183-1190.

[17] Mehmet Saltan, Betul Oksuz and Volkan Emre Uz (2015), "Use of glass waste as mineral filler in hot mix Asphalt" Sci Eng Compos Mater 2015; 22(3): 271-277.

[18] MORTH, Specification for Road and Bridge work $5^{\text {th }}$ revision 2013.

[19] Mahabir Panda and Mayajit Mazumdar (2002) "Utilization of reclaimed polyethylene in bituminous paving mixes", J. Mater. Civ. Eng., 14(6), 527-530.

[20] Sandeep Karmakar and Tapas Kumar Roy (2016), "Effect of waste plastic and waste tires ash on mechanical behavior of bitumen" Journal of Materials in Civil Engineering Vol. 28, Issue 6 (June 2016). 